\title{
Łukasz Storch
}

Uniwersytet Szczeciński

\section{ZDOLNOŚĆ DO BYCIA W DIALOGU JAKO KOMPETENCJA KOMUNIKACYJNA W KONTEKŚCIE DOZORU KURATORSKIEGO}

\begin{abstract}
The ability to be in dialogue as communicative competence in the context of supervision curatorial

The pedagogy correctional probation as part of the curatorial supervision depends on the choice of the type of interaction and forms, and success in their important role played by probation officers. The interactions between probation officer and the ward reveals a dialogical space that relationship. It has many forms, among which we can mention, among others, "meeting" and "dialogue". This fits in with the philosophy and existential dialogue presented by Martin Buber, according to which a real conversation, thus fulfilling the relationship between human beings constitutes acceptance of otherness. "Humanity and humanity become real meetings. People need and can also confirm each other in their individual being". The process of rehabilitation requires dialogical proceedings against ward. Dialog fact closer to the people by its openness and reciprocity. According to Stanislaw Sławiński, "dialogue is a conversation free from all adulteration, and so the caller must see each other in person, to be honest, and at the same time what they say must coincide with the real facts. They need to talk to each other about something they believe is important, what makes really want to give something back and something from the other side to hear". You can refer to the nature of the phenomena associated with the activities of probation, in which special significance is dialogic aspect.
\end{abstract}

Key words: probation, curator, dialogue, personalization, rehabilitation, probation, existentialism, competence, communication

\section{Wprowadzenie}

Inspiracją do napisania niniejszego tekstu była lektura działa filozoficznego Martina Bubera pod tytułem $\mathrm{Ja} i \mathrm{Ty}$. Poszczególne frazy autora wzbudziły refleksję nad przestrzenią dialogiczną relacji pomiędzy kuratorem sądowym a podopiecznym. Szczególną uwagę zwracają słowa, że:

Prawdziwa rozmowa, a tym samym spełnienie relacji między ludźmi oznacza akceptację inności. [...] Ludzkość i człowieczeństwo stają się w spotkaniach prawdziwych. [...] Ludzie potrzebują 
i mogą zarazem potwierdzać się nawzajem w swoim indywidualnym bycie. Jednocześnie potrzebują i zarazem mogą inaczej naświetlać innym ludziom zbadaną przez duszę prawdę i w ten sposób oglądać ją potwierdzoną (Buber 1992: 135).

Rozmowa oznacza dialog prowadzony przez uczestników spotkania. W poniższych rozważaniach postaram się dokonać sygnifikacji różnych wymiarów relacji między podmiotami spotkania.

Kategoria „dialogu” wyprowadzana z języka greckiego od słowa lógos (słowo, mowa, wypowiedź) oraz diá (jako zaimek oznaczający przejście przez coś lub ruch polegający na przechodzeniu $\mathrm{z}$ jednego punktu do drugiego) zastosowana jest tutaj w znaczeniu przeciwnym do monologu, gdy możemy stwierdzić, że jest tu i jedno, i drugie. Kategoria „dialog” oznacza także ruch, który możemy ująć jako wyjście i powrót słowa w relacji między dwoma lub więcej rozmówcami. Możemy tą kategorią określić również samo rozmawianie lub znajdowanie drugiego. Przytoczony opis etymologiczny nie przybliża nam całego bogactwa, jakie zawiera w sobie „dialog” związany z życiem człowieka w swoim wszechstronnym znaczeniu (Nowak 2010).

Zanim jednak dojdzie do „spotkania” kuratora z podopiecznym, zachodzi zjawisko konfliktu społecznego wynikającego $\mathrm{z}$ dopuszczenia się przez sprawcę czynu zabronionego przez prawo. Prawo karne, w ramach którego funkcjonuje polski system probacji, skupia się nie tylko na wymierzeniu kary za popełnienie przestępstwa, lecz też pełni funkcję zapobiegawczą i wychowawczą wobec społeczeństwa. Karą w rozumieniu kodeksowym jest orzekany przez sąd wobec sprawcy przestępstwa środek przymusu państwowego, stwarzający dla niego osobistą dolegliwość i wyrażający społeczne potępienie dla popełnionego przestępstwa. Natomiast „Probacja jest metodą postępowania z osobami, które z powodu popełnienia przestępstwa poddano próbie, wiążąc je z określonymi warunkami oddania pod dozór sądowy i związany z nim systemem resocjalizacji” (Pawela 1977: 28). Jest to system pozwalający na odbywanie kary poza więzieniem, służący resocjalizacji winnego zarzucanego mu czynu zabronionego. Zazwyczaj stosowany jest wobec osób skazanych na karę pozbawienia wolności (Bałandynowicz 2004).

Aktywność probacyjna kuratorów sądowych przejawia się poprzez prowadzane dozory nad skazanymi. Kontrolna, profilaktyczna i resocjalizacyjna działalność, realizowana w ramach kuratorskiego dozoru sadowego, obejmuje: inspirację podopiecznego do wyznaczania sobie celów bieżących i długookresowych, adekwatnych do jego potencjału i potrzeb, instruowanie w prowadzonej sprawie o realnych sposobach wywiązania się z obowiązków oraz pomoc w osiąganiu wyznaczonych celów. Kuratela sądowa to metoda społecznego i indywidualnego działania wychowawczego odbywającego się w warunkach naturalnego środowiska skazanego, a więc w jego domu, pracy, szkole czy w czasie wolnym. Ma to na celu uzyskanie poprawy jego zachowania oraz wypracowanie u niego zachowań prawidłowych i pozytywnych ze społecznego punktu widzenia. Nie może więc być rozumiana jako kara dla skazanego ani nie jest zamazaniem jego przestępczego zachowania w przeszłości czy formą przebaczenia (Czapów, Jedlewski 1971). Cele dozoru kuratorskiego to: rehabilitacja przestępców, udzielenie im pomocy w tym, by mogli 
prowadzić życie zgodnie z prawem, ochrona społeczeństwa, umożliwienie przestępcy wykazania się poprawą i udowodnienia, że nie dojdzie do dokonania podobnego czynu w przyszłości, kontrola $\mathrm{z}$ wywiązywania się z obowiązków nałożonych na przestępcę przez sąd (Ostrihanska, Greczuszkin 2005).

Aby zaistniały powyższe oddziaływania i przyniosły oczekiwane rezultaty, konieczne jest posiadanie przez kuratorów sadowych odpowiednich kompetencji. Maria Czerepaniak-Walczak formułuje jedną z definicji kompetencji jako: harmonijną kompozycję wiedzy, sprawności, rozumienia oraz pragnienia. Wyrażona myślą - „pragnę to zrobić dobrze; szczególna właściwość, wyrażająca się w demonstrowaniu na wyznaczonym przez społeczne standardy poziomie, umiejętności adekwatnego zachowania się, w świadomości potrzeby i konsekwencji takiego właśnie zachowania oraz w przyjmowaniu na siebie odpowiedzialności za nie" (Czerepaniak-Walczak 1997: 87, 88). Ta sama autorka przytacza definicje kompetencji ukute przez innych autorów. Kompetencja to, według O.H. Jenkinsa, zdolność i gotowość do wykonywania zadań na określonym poziomie; według D. Fontany wyuczalna umiejętność robienia rzeczy dobrze, sprawności niezbędne do radzenia sobie z problemami. Natomiast Maria Dudzikowa stwierdza, że pojęcie kompetencji staje się we współczesnych nurtach pedagogiki paradygmatem (Dudzikowa 1996). Interpretuje ona kompetencję jako umiejętność wyższego rzędu będącą skutkiem osiągniętym przez ćwiczenie umiejętności i nabywanie doświadczeń, podbudowanych przekonaniem, pewnością opartą na refleksji, dlaczego trzeba postąpić w określony sposób w określonej sytuacji. Stanowisko to uzasadnia się koniecznością takiego przygotowania człowieka, aby był on zdolny do ciągłego uczenia się, ciągłego samorozwoju, autokreacji, co warunkuje jego adaptowanie się do zmieniających się warunków całego okresu aktywności życiowej i zawodowej. Maria Dudzikowa wymienia kompetencje: poznawcze, interpretacyjne, emancypacyjne, interpersonalne, komunikacyjne, życiowe, artystyczne, techniczne, kulturowe oraz kompetencje koordynowania rozbieżnych perspektyw, jakie niosą antynomie demokracji.

W odniesieniu do tematyki dialogu pozostaniemy w sferze kompetencji komunikacyjnej. Kompetencje komunikacyjne to dialog wielostronny i nie chodzi tu tylko o sam przekaz w kategoriach komunikacji, lecz o przyjęcie określonej perspektywy etyczno-filozoficznej (Kwaśnica, Semkow 1995). Powinno pozwolić to kuratorowi być w dialogu z innymi i samym sobą. Rozmowa w relacji dwustronnej - kurator-podopieczny (krytyczne myślenie i rozwiązywanie problemów, kreatywność i innowacyjność, jasne komunikowanie, dzielenie się wiedzą i doświadczeniem, ale również wykorzystanie narzędzi informacyjno-komunikacyjnych w celu przetwarzania informacji ), kurator-inni kuratorzy (z większym lub mniejszym stażem pracy i doświadczeniem), kurator-zwierzchnicy (np. współpraca, współdecydowanie, inicjatywa, produktywność), kurator-rodzina podopiecznego (wszystkie sytuacje współpracy, współdziałania, spotkania, wspólne rozwiązywanie problemów) - pozwala na pełne wykorzystanie kompetencji komunikacyjnych niezbędnych do dialogowania. 


\section{Relacja dialogiczna w ujęciu filozoficznym}

Niewątpliwie proces resocjalizacji wymaga dialogicznego postępowania wobec podopiecznego. Dialog bowiem zbliża ludzi przez swoją otwartość i wzajemność. Według Stanisława Sławińskiego

dialog to rozmowa wolna od wszelkiego zafałszowania, a więc rozmówcy muszą widzieć w sobie nawzajem osoby, muszą być szczerzy, a równocześnie to, co mówią, musi pokrywać się z rzeczywistymi faktami. Muszą mówić z sobą o czymś, co w ich przekonaniu ma znaczenie, co sprawia, że rzeczywiście pragną coś od siebie przekazać i coś od drugiej strony usłyszeć (Sławiński 1998: 33).

Dialog, zgodnie z tym, nie znosi pozorów i kłamstwa. Wymaga natomiast skupienia i staranności, a także uwagi zarówno w słuchaniu drugiego człowieka, jak i w wypowiadaniu własnych myśli. Dialog łączy się z dobrowolnym procesem oddziaływania na drugiego człowieka, nie zakłada porażki i wprowadza przekonanie o słuszności podejmowanych działań wychowawczych. W tym zakresie nie można okazywać rozczarowania i zniechęcenia wobec wychowanka, któremu powinno się pomóc, nie narzucając własnych rozwiązań jako ostatecznych, lecz pozwalając na aktywny udział w procesie wychowawczym (Iwański 2015).

Mówiąc o dialogu jako rozmowie, mamy na myśli wymianę informacji pomiędzy dwoma lub więcej osobami. Właśnie ta relacja stanowi ważny element analizy dialogu jako spotkania (Rosner 2011). Potwierdzenie takiego ujęcia odnajdujemy u czołowego przedstawiciela filozofii dialogu Martina Bubera, który pisał, że: „na początku jest relacja”, dialog natomiast ,jest postępowaniem ludzi wobec siebie, znajdującym jedynie wyraz w komunikacji” (Buber 1992: 209, 214). Filozofia dialogu rozwijała się w XX wieku (Tyburski 2000). W swoich poglądach filozofowie dialogu uznawali doświadczanie czegoś jako bardziej znaczące niż poznanie. Myślą przewodnią stał się człowiek i jego relacja z drugim człowiekiem. Drugi człowiek został uznany za fundamentalną realność doświadczenia emocjonalnego, a więź i relacja z nim podniesiona do rangi czegoś najbardziej naturalnego i koronnego dla człowieka umiejscowionego w świecie (Gara 2006).

Martin Buber w początkach swojej twórczości pozostawał pod wpływem mistycyzmu niemieckiego oraz Kabały, z czasem stopniowo odchodził od filozofii jedności, w której widoczne było dążenie do wzniesienia się ponad naznaczoną wielością rzeczywistość, ku filozofii dialogu, kładącej nacisk na inność, odrębność i relacyjność oraz afirmującej świat. Według Martina Bubera sfera międzyludzka uzyska urzeczywistnienie w uobecnieniu. Opiera się to na zdolności, którą ma każdy z nas i nazywa realną fantazją: czyli zdolność do oglądania oczyma duszy istniejącej w danym momencie rzeczywistości, chociaż niedoświadczanej zmysłowo. Wyobrażenie o tym, co myśli i przeżywa czy czuje drugi człowiek, zostaje umiejscowione w jego rzeczywistości. Przykładem może być współczucie i współcierpienie (Buber 1992). W różnych aktach międzyosobowych, na przykład we współczuciu, współcierpieniu, drugi ujawnia się jako „jaźń-dla-mnie”. 
Człowiek chce być potwierdzony przez człowieka w swoim bycie i chce być obecny w bycie drugiego. Osoba ludzka potrzebuje potwierdzenia, ponieważ potrzebuje go „człowiek jako człowiek”. Pradystans przeradza się więc w relację Ja-Ty, w której drugi staje się jaźnią-dla-mnie, staje się jaźnią-wraz-ze-mną. „Ludzie podają sobie niebiański chleb bycia jaźnią". Tymczasem w relacji Ja-Ty Ty jawi się wprost, bezpośrednio, całościowo. Doświadczenie rozczłonkowuje drugiego na szereg zaobserwowanych własności. Relacja Ja-Ty ujawnia osobę w jej całości, a nie jako rzecz złożoną z różnych części. Ty jest obecne, a opisy zewnętrznych właściwości nie mają znaczenia. „Ty spotyka mnie” (Buber 1992: 45). „Wobec bezpośredniości relacji nieistotne staje się wszystko, co pośrednie” (Buber 1992: 74). Wszystko zaczyna się od obecności Ty, od spotkania. „Ty wypełnia horyzont. Nie żeby nic poza nim nie istniało: wszystko jednak żyje w jego świetle"(Buber 1992: 43). Ty zjawia się bezpośrednio, zaprasza do istotowego czynu człowieka. Domaga się odpowiedzi całego Ja, które nie może w tej odpowiedzi nic zachować dla siebie (Buber 1992).

Według Martina Bubera Drugiego możemy uprzedmiotowić, relacja Ja-Ty jest jednak pierwotna.

Nieprawdą jest, że dziecko postrzega najpierw przedmiot, a później wchodzi z nim w relację. Pierwsze jest dążenie do relacji - wyciągnięta ręka, w którą wtula się Naprzeciw. (...) Stanie się rzeczą jest natomiast późniejszym produktem, który wyłania się z rozkładu praprzeżyć, z rozłączenia się złączonych partnerów (Buber 1992: 55).

Relacja do Ty jest czymś wrodzonym, apriorycznie poprzedza wszystko. Ja pojawia się w wyniku realizacji relacji. „Człowiek staje się Ja w kontakcie z Ty”. Zdaniem Martina Bubera opis kontaktów międzyludzkich zostaje zdominowany przez podejście analityczne, redukcyjne, utylitarne, narzucone przez nauki przyrodnicze. W tej perspektywie ujmuje się człowieka poprzez jego genezę i funkcjonowanie w zdeterminowanych strukturach. Dominacja takiego ujęcia niweluje to, co osobowe w człowieku. Wszystko chce się wyrazić przez struktury pozaosobowe. Tymczasem odkrycie Ja poprzez Ty możliwe jest poprzez bezpośrednią intuicję, poprzez bezpośrednie wkroczenie, wyjście naprzeciw realnej osoby w jej jedności, całości i niepowtarzalności (Buber 1992).

W relacji Ja-Ty można dostrzec problematykę jej dwustronności i wzajemności. Nietrudno znaleźć przykłady ograniczenia wzajemności. Pochodzą one z naszych niewłaściwych postaw i uprzedzeń. Możemy patrzeć na potrzebującego bliźniego obco, nieprzyjaźnie. Możemy go traktować jak natręta. Odnosimy się do różnych grup ludzi z rezerwą i dystansem. Wzajemność we współżyciu ludzi nie jest więc czymś, co automatycznie zachodzi. W niektórych zależnościach między ludźmi nie może się rozwinąć pełna ich wzajemność. W relacji między kuratorem a podopiecznym z natury rzeczy ograniczona jest ona w swej wzajemności. Ważne staje się nawiązanie wzajemnego dialogu w celu diagnozy sytuacji, aby rozpoznać błędne procesy socjalizacyjne. W wyniku tego podopieczny może sobie uświadomić różne „dolegliwości” i uporządkować swoje życie. Brak takiego podejścia może prowadzić do tego, że obaj nie wiedzą, jak dokonać 
„regeneracji skarłowaciałego osobowego centrum”. Jak dalej pisze Martin Buber, „Może dokonać tego tylko ten, kto doświadczonym spojrzeniem lekarza obejmuje rozproszoną, ukrytą jedność cierpiącej duszy, co jest osiągalne tylko w partnerskim obcowaniu osoby z osobą, a nie poprzez rozpatrywanie i badanie przedmiotu"(Buber 1992: 152).

\section{Dialog w resocjalizacji z udziałem kuratora sądowego}

Zwłaszcza na początku okresu próby relacje między kuratorem a dozorowanym bywają trudne, ponieważ z reguły jest on dość negatywnie nastawiony i nie posiada dostatecznej motywacji do zmiany swojego postępowania. Kurator, oprócz działań wychowawczych i działań z zakresu pomocy i opieki nad dozorowanym, z racji wymogów przypisanych ustawowo temu zawodowi sprawuje również rolę nadzorczą nad jego postępowaniem. Dozór dotyczy kontroli zachowania i postępowania skazanego ze względu na przestrzeganie przez niego porządku prawnego i wykonywanie postanowień wyroku sądowego oraz narzuconych w nim obowiązków. Model nadzoru kontrolno-represyjnego nad skazanym powoduje, że odczuwa on przymus związany z koniecznością realizowania zasądzonych rygorów i ma świadomość, że gdy ich nie zrealizuje, jego sytuacja ulegnie zdecydowanemu pogorszeniu. Natomiast kuratela wychowująca polega na przyjaznej relacji między kuratorem a podopiecznym, co powoduje, że łatwiej jest mu wpłynąć na kreowanie u skazanego pożądanych postaw i wartości, a także na zmianę jego postępowania i zachowania. Współpraca kuratora z podopiecznym oparta jest na zrozumieniu jego sytuacji oraz poznaniu motywacji kierujących jego postępowaniem. Ten typ kurateli może być realizowany głównie przy wykorzystaniu metody pracy z indywidualnym przypadkiem. Oparty jest najczęściej na kontrakcie sformułowanym na początku próby i obowiązującym obie strony. W dłuższej perspektywie czasowej model kurateli wychowującej zdaje się bardziej korzystny niż model kontrolujący: (1) w odniesieniu do całego społeczeństwa, które spodziewa się znalezienia efektywnych sposobów przeciwdziałania i zapobiegania przestępczości; (2) w odniesieniu do sędziów i kuratorów, którzy, znając z praktyki tę problematykę, szukają najskuteczniejszych metod resocjalizacji, oraz (3) samych podopiecznych, którzy są traktowani podmiotowo i biorąc udział w procesie resocjalizacyjnym w ramach tego modelu, mają możliwość dokonywania zmian w swoim życiu na zasadach partnerskich z kuratorami (Kępka 2007).

Działalność wychowawcza kuratora sądowego sprowadza się do oddziaływania kształtującego i korygującego aktywność podopiecznego, określającą walory pełnienia oraz rodzaj przypisanych mu ról społecznych. Pomoc udzielana przez kuratora resocjalizowanemu powinna zmierzać do poprawy warunków wychowawczych, usunięcia zbyt trudnych dla niego przeszkód codziennego życia oraz pobudzenia go do działania (Pytka 2000). Kurator sądowy powinien nie tylko sterować procesem wychowania, lecz również pełnić rolę przewodnika i doradcy swego podopiecznego. Związana jest $z$ tym integralnie działalność opiekuńcza skierowana na tworzenie możliwości zaspokojenia jego socjo- i psychogennych potrzeb, których niespełnienie było jedną z głównych 
przyczyn rozpoczęcia działalności przestępczej (Gromek 2002). Powinien dostrzegać w podopiecznym jego cechy charakteru, jego talenty i możliwości, które chce rozwinąć. „Musi jednak widzieć w nim nie tylko sumę właściwości, dążeń i zahamowań, lecz postrzegać go jako całość i w tej jego całości go akceptować. Ale może to uczynić tylko wtedy, gdy spotyka go za każdym razem w dwubiegunowej sytuacji jako partnera" (Gromek 2002: 154). Gdy obudzi się między nimi wzajemna relacja Ja-Ty, wtedy mamy do czynienia $\mathrm{z}$ wzajemną akceptacją osób i możliwa jest resocjalizacja.

Główną ideą takiego dialogu jest nieustanne tworzenie oraz przezwyciężanie różnic znaczeń, dziejące się poprzez wymianę myśli, będące aktywnością ustawiczną, ludzkim sposobem bycia. $W$ tym przypadku rozumienie nie oznacza więc odtwarzania ustalonych już znaczeń. Zatem o dialogu stanowi rozmowa, co przejawia się tym, iż dana osoba wypowiada w niej swoje myśli, kierując się poszukiwaniem na przekór utartym schematom. Jak pisał Hans Georg Gadamer, spotkanie dwojga ludzi zawsze zakłada spotkanie dwóch światów, dwóch spojrzeń na nie oraz dwóch obrazów świata wkraczających w siebie nawzajem. Dalej powołując się na tego autora, rozmowa jest rozmową nie dzięki temu, iż doświadczyliśmy w niej czegoś nowego, a dlatego, iż napotkaliśmy w drugim człowieku coś, czego jeszcze w naszym doświadczeniu świata nie spotkaliśmy (Gadamer 1980). Według Joanny Rutkowiak taki dialog stanowi warunek wzajemnego zrozumienia. Ponadto nie jest w nim ważne samo spotkanie czy przeciwieństwo dwóch osób, lecz ich dwa odmienne światy, wyartykułowane w języku, w którym używanie słów nie oznacza podporządkowania ich ściśle określonym i gotowym sensom oraz jasnym i wyraźnym pojęciom (Rutkowiak 1992).

Odnosząc relację kurator-podopieczny do dialogu, dominujące w rzeczywistości probacyjnej jest podejście, według którego kurator tylko przekazuje ustalone przepisami i orzeczeniem treści, a dozorowany staje się jedynie obiektem jego oddziaływań. Podając za Marianem Nowakiem, Paulo Freire pisał, że podejście takie w praktyce dialogu powinno być wypierane przez to, które można określić jako „otwarte i personalistyczne”, a według którego wszyscy pozostają w dialogu, oddziałując na siebie każdy na swój sposób. Pozostawać zaś „otwartym” oznacza, że w dialogu cała nasza uwaga powinna być skierowana na Innego, a nie na nas samych. Nie należy zapominać również o posiadaniu własnego spojrzenia i własnych ideałów oraz konieczności konfrontowania się ze zdaniem innych, gdy posiadamy na ten temat własną opinię czy argumentację (Nowak 2010).

Idea dialogu rodzi poważny problem relacji między autorytetem kuratora a dozorowanego, który możemy ująć jako problem relacji między autorytetem a wolnością. Działalność kuratorska w tym kontekście polega na kształtowaniu osobowości podopiecznego do zdolności wolnej akceptacji dobra, jaką jest osiągnięcie rezultatu wolności jego motywów. W związku z tym podstawowe zadanie kuratora nie powinno polegać na przedstawianiu podopiecznemu motywów, które przez ich wartość i wagę byłyby niepodważalne, lecz na wspieraniu go, aby potrafił wartościować i docenić samą wartość tych motywów, jakie zostaną mu zaproponowane w różnych sytuacjach życiowych, oraz dokonywać wyborów opartych na zasadach moralnych (Nowak 2010). 
Resocjalizacja w ramach probacji powinna zakładać podjęcie dialogu z podopiecznymi i poszukiwanie wraz z nimi prawdy, w której kurator sądowy, bez utraty swojej tożsamości, dzieli się swoim doświadczeniem i swoją wiedzą z wychowankami. Pozostaje także otwarty i w dyspozycji do przyjęcia tego, co również dozorowani wnoszą. Konstruowana w ten sposób relacja powinna zmierzać do dialogowania $z$ innymi osobami, przyjmowania nowych wartości i ich respektowania. Przez to praca probacyjna z udziałem kuratorów sądowych powinna obejmować nabywanie coraz większej liczby wszelakich dyspozycji, włącznie z umiejętnością dialogu dotyczącego podstawowych idei i ideałów, zmiany własnych przekonań, własnej tożsamości, wiedzy i kultury (Nowak 2010).

Istota dialogu wiąże się z relacją człowieka $\mathrm{z}$ człowiekiem, w której zacierają się różnice związane $\mathrm{z}$ wiekiem i rolami, natomiast budzi się sympatia i zainteresowanie, wzajemne komunikowanie i gotowość do uwzględnienia słów i perspektywy patrzenia drugiego, aż do zdolności patrzenia na rzeczy z pozycji drugiego. Aby tego rodzaju warunki mogły zaistnieć, konieczna jest po stronie dozorowanego postawa relaksu, która pozwala na redukcję napięcia i usunie lęk wobec powstających trudności życia. Wyniki w procesie resocjalizacji w ramach probacji nie są najczęściej bezpośrednie czy natychmiastowe ani nie zawsze zadowalające. Dialog powinien być nakierowany na porozumienie i zrozumienie się między kuratorem a podopiecznym oraz prowadzić do efektu zrozumienia samego siebie i otaczającego świata. W oddziaływaniach probacyjnych jest nieodzowna ciągła reorganizacja świata poznawanego przez dozorowanego, gdyż jego osobowość jest poddawana ewolucyjnemu rozwojowi i podlega w rezultacie głębokim przemianom. I to właśnie tego rodzaju reorganizacja własnej percepcji, nastawiona na obudzenie w jednostce uczuć i postaw o charakterze pozytywnym, stanowi już sama w sobie ważny element pedagogiczny o wielkim znaczeniu (Nowak 2010).

\section{Podsumowanie}

Właśnie stylowi pracy kuratora sądowego sprzyja postawa uwrażliwiona na prowadzenie dialogu zmierzająca do rozumienia tego, co jego podopieczny odczuwa, o co mu naprawdę chodzi. Można się odnieść do tego tak, jak Carl Ransom Rogers postrzega sposób bycia z drugim człowiekiem jako

wejście w prywatny świat czyjejś percepcji i zadomowienie się w nim. Oznacza, że ma się nieustannie wyostrzoną wrażliwość na zmiany znaczeń i odczuć drugiego człowieka, na jego lęk, wściekłość i czułość, zakłopotanie, na wszystko, co on przeżywa (Rogers 1991: 9).

Przedstawiony sposób bycia wymaga ogromnej siły i subtelności w codziennych relacjach międzyludzkich, tym bardziej trudny jest w sytuacjach obarczonych zależnością, a przecież także przeszłością przestępczą jednej ze stron. Kurator musi być jednak świadomy przeżyć, doznań, na które narażony jest dozorowany. W środowisku otwartym często dochodzi do różnorodnych sytuacji dających wyraz piętnowania osób z przeszłością 
przestępczą. Tylko empatyczny kontakt kuratora z podopiecznym pozwala na szczerość we wzajemnych relacjach. Empatia jest nieustannie trwającym procesem, wymagającym pielęgnacji, doskonalenia. Doświadczenia życiowe, różne sytuacje, w których człowiek uczestniczy w swoim życiu, mogą zarówno osłabiać, jak i wzmacniać empatyczność. Należy mieć to na uwadze szczególnie w przypadku osób zatrudnionych w tzw. profesjach pomocowych, a także w relacjach z osobami z przeszłością przestępczą. Systematyczna weryfikacja umiejętności empatycznych, a także kształtowanie ich poprzez różnorodne treningi są koniecznością. Jednym z elementów umożliwiających wzmacnianie empatycznych relacji jest umiejętność prowadzenia dialogu. Niestety, zbyt często w procesie resocjalizacji monolog dominuje nad dialogiem. Nieumiejętność słuchania to częsta wada zauważana u osób odpowiedzialnych za przebieg procesu resocjalizacji (Fidelus 2010).

W procesie dialogu uczestniczą co najmniej dwie osoby. W pracy resocjalizacyjnej intensywne relacje interpersonalne przebiegają „twarzą w twarz”, uczestnicy mają z sobą bezpośredni kontakt. W procesie tym kurator w postaci myśli uświadamia sobie, co chce przekazać swojemu podopiecznemu. Koduje to na znaki w postaci słów i aspektów mowy niewerbalnej i wysyła do adresata, który odbiera informacje za pomocą zmysłu wzroku i słuchu. Podopieczny odkoduje odebraną informację, przetwarza ją, po czym następuje natychmiastowe sprzężenie zwrotne w postaci wypowiedzi słownej, zachowania lub zakodowania. W tym przypadku nie ma pewności, jakie znaczenie nadał podopieczny przekazowi, który otrzymał. Nie zawsze odbiorca odczytuje dany komunikat w takim samym znaczeniu, jakie nadał nadawca. $Z$ tego powodu występują liczne nieporozumienia w relacjach interpersonalnych. Doskonały dialog jest wtedy, gdy odbiorca uzyskuje taki sam obraz komunikatu, jaki został utworzony w umyśle nadawcy. Jednak aby to nastąpiło, osoby biorące udział muszą pracować nad swoimi umiejętnościami. Jest to ważne w każdej relacji interpersonalnej. Można więc zauważyć, że umiejętność w zakresie dialogowania to bardzo ważna predyspozycja dla osób działających w dziedzinie pracy resocjalizacyjnej i probacyjnej. Należy zatem podkreślić złożoność podmiotowości osoby niosącej pomoc jednostce. W polskim systemie są to kuratorzy sądowi, pedagodzy, terapeuci i pracownicy socjalni (Walczak-Duraj 2009). W rzeczywistości mamy do czynienia z wieloma pracownikami wymiaru sprawiedliwości, pomocy społecznej oraz urzędnikami, którzy nie są przygotowywani w zakresie umiejętności dialogu w prowadzanym procesie oddziaływania. $Z$ założenia problemy należy rozwiązywać wspólnie w celu osiągnięcia wspólnego dobra. Podkreśla się w ten sposób szczególną interakcję pomiędzy kuratorem a podopiecznym, pomiędzy osobą nawiązującą stosunek pomocowy a osobą, która jest jej adresatem (Bałandynowicz 2012a). Wspólne rozwiązywanie oznacza nienarzucanie decyzji, jest to spotkanie mające na celu dialog poprzez wysłuchanie osoby potrzebującej oraz uzgodnienie wzajemnego postępowania, czyli skoordynowanie działań. Jest to zatem szczególny i wymagający rodzaj interakcji społecznej. 


\section{Bibliografia}

Bałandynowicz A. (2004). Rekomendacje do artykułu: System probacji propozycja racjonalnego, sprawiedliwego i efektywnego karania, w: Senat Rzeczypospolitej Polskiej, Zapobieganie $i$ zwalczanie przestępczości w Polsce przy zastosowaniu probacyjnych środków karania. Materiały z konferencji zorganizowanej przez Komisję Ustawodawstwa i Praworządności pod patronatem Marszałka Senatu RP Longina Pastusiaka.

Bałandynowicz A. (2011). Probacja. Resocjalizacja z udziałem społeczeństwa. Wolters Kluwer Polska, Warszawa.

Bałandynowicz A. (2012a). Podmiotowość osoby i dobro wspólne w procesie reintegracji społecznej a system probacji. „Probacja”, 1: 32-60.

Bałandynowicz A. (2012b). Rozważania nauki w kwestii roli służb probacyjnych $w$ resocjalizacji sprawców przestępstw. „Probacja”, 1: 118-125.

Buber M. (1992). Ja i Ty, tłum. J. Doktór. PAX, Warszawa.

Czapów C., Jedlewski S. (1971). Pedagogika resocjalizacyjna. Wydawnictwo Naukowe PWN, Warszawa.

Czerepaniak-Walczak M. (1997). Aspekty iźródła profesjonalnej refleksji nauczyciela. Edytor,Toruń.

Dobek-Ostrowska B. (2006). Komunikowanie polityczne i publiczne. Podręcznik akademicki. Wydawnictwo Naukowe PWN, Warszawa.

Dudzikowa M. (red.) (1996). Nauczyciel-uczeń. Między przemocą a dialogiem: obszary napięć i typy interakcji. Wydawnictwo Impuls, Kraków.

Dziewiecki M. (2000). Psychologia porozumiewania się. Wydawnictwo „Jedność”, Kielce.

Fidelus A. (2010). Podejście nastawione na osobę w procesie resocjalizacji. „Probacja”, 1: 69-79.

Gadamer H.G. (1980). Niezdolność do rozmowy, tłum. B. Baran. „Znak”, 3: 369-376.

Gara J. (2006). Pedagogiczne konteksty tez filozofii i dialogu, „Człowiek - Niepełnosprawność - Społeczeństwo", ?: 12.

Głodowski W. (1994). Komunikacja interpersonalna. Wydawnictwo Polskiego Towarzystwa Psychologicznego, Warszawa.

Golka M. (red.) (2000). Bariery w komunikowaniu. Wydawnictwo Uniwersytetu im. Adama Mickiewicza, Poznań.

Gromek K. (2002). Kuratorzy sadowi. Komentarz do ustawy z 27 lipca 2001 r. Wydawnictwo Prawnicze. Grupa LexisNexis, Warszawa.

Iwański Z.S. ks. (2015). Personalizacja skazanych w procesie resocjalizacji. „Probacja”, 2: 128-132.

Kępka S. (2007). Kuratela sądowa: wychowująca czy kontrolno-represyjna? Ujęcie formalnoprawne, w: E. Bielecka (red.), Profilaktyka i readaptacja społeczna - od teorii do doświadczeń praktyków. Wydawnictwo Uniwersyteckie Trans Humana, Białystok: 67.

Kwaśnica R., Semkow J. (red). (1995). Ku dialogowi w pedagogice. IV Forum Pedagogów, Wrocław. Nowak M. (2010). Dialog w wychowaniu. „Pedagogika Christiana”, I: 25.

Ostrihanska Z., Greczuszkin A. (2005). Praca $z$ indywidualnym przypadkiem w nadzorze rodzinnego kuratora sądowego. Norbertinum, Lublin.

Pawela S. (1977). Resocjalizacja recydywistów w systemie nadzoru ochronnego. Wydawnictwo Prawnicze, Warszawa. 
Pytka L. (2000). Pedagogika resocjalizacyjna. Wybrane zagadnienia teoretyczne, diagnostyczne i metodyczne. Wydawnictwo Akademii Pedagogiki Specjalnej, Warszawa.

Rogers C.R. (1991). Terapia nastawiona na klienta. Grupy spotkaniowe, tłum. A. Dodziuk, E. Knoll. Thesaurus-Press, Wrocław.

Rosner K. (2011). Dialog jako temat filozofii i współczesnej: Buber, Gadamer, Habermas, w: Dialog, idea i doświadczenie, red. S. Kruszyńska, K. Bembennek, I. Krupiecka. Wydawnictwo Uniwersytetu Gdańskiego, Gdańsk: 15

Rutkowiak J. (red.) (1992). Pytanie, dialog, wychowanie. PWN, Warszawa.

Sławiński S. (1998). Dojrzewać do miłości. Instytut Wydawniczy PAX, Warszawa.

Stewart J. (red.) (2008). Mosty zamiast murów. Podręcznik komunikacji interpersonalnej, tłum. J. Suchecki. Wydawnictwo Naukowe PWN, Warszawa.

Tyburski W. (2000). Idea dialogu w dziejach filozofii, w: Filozofia dialogu, red. M. Kallas. Towarzystwo Naukowe, Toruń: 15-39.

Walczak-Duraj D. (red.) (2009). Wartości i postawy młodzieży polskiej, t. 1-2. Wydawnictwo Uniwersytetu Łódzkiego, Łódź.

Żółkowska T. (2013). Ja-Ty - Inny Dialog. „Studia Edukacyjne”, 28: 17-32. 